\title{
Commentary: Beyond the edge of the map
}

Joseph S. Coselli, MD

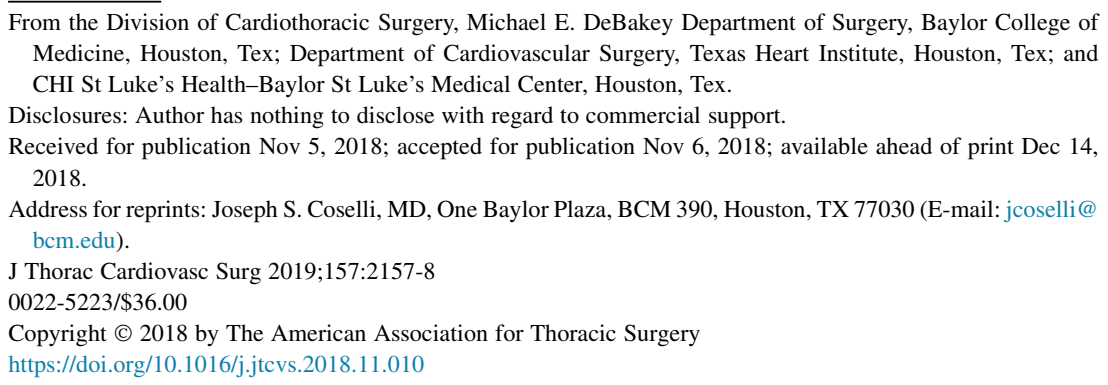

From the Division of Cardiothoracic Surgery, Michael E. DeBakey Department of Surgery, Baylor College of Medicine, Houston, Tex; Department of Cardiovascular Surgery, Texas Heart Institute, Houston, Tex; and CHI St Luke's Health-Baylor St Luke's Medical Center, Houston, Tex.

Disclosures: Author has nothing to disclose with regard to commercial support.

Received for publication Nov 5, 2018; accepted for publication Nov 6, 2018; available ahead of print Dec 14, 2018.

Address for reprints: Joseph S. Coselli, MD, One Baylor Plaza, BCM 390, Houston, TX 77030 (E-mail: jcoselli@ bcm.edu).

J Thorac Cardiovasc Surg 2019;157:2157-8

0022-5223/\$36.00

Copyright (C) 2018 by The American Association for Thoracic Surgery

https://doi.org/10.1016/j.jtcvs.2018.11.010

In this issue of the Journal, Schoenhoff and colleagues ${ }^{1}$ present their analysis of 100 consecutive patients with Marfan syndrome, all of whom fulfilled the revised Ghent criteria. ${ }^{2}$ These patients were followed up for more than a decade and underwent 34 interventions related to nonaortic arterial segments, in addition to 158 thoracic, thoracoabdominal, and abdominal aortic interventions. The authors point out that little is known regarding the incidence and clinical relevance of nonaortic arterial aneurysms in patients with Marfan syndrome, but that these aneurysms may be more common than many realize. Peripheral aneurysms such as these have received more attention in patients with other connective tissue disorders (eg, Loeys-Dietz syndrome, Ehlers-Danlos syndrome). Notably, there are few data on the size of peripheral arteries, even in healthy individuals. Whereas efforts have been made to determine normal ranges of aortic diameter by age, gender, body surface area, and other parameters, this depth of information is simply not available for peripheral artery dimensions. The authors relied on arterial reference values provided by Johnston and colleagues, ${ }^{3}$ working on behalf of the subcommittee on reporting standards for arterial aneurysms for the Society of Vascular Surgery. Because this source did not include reference values for the dimensions of the subclavian artery, the authors turned to the work of Thrush and Hartshorne, ${ }^{4}$ who chiefly used peripheral vascular ultrasonography to obtain these values.

It is well known that the aortopathy of Marfan syndrome, as well as other connective tissue disorders, requires lifelong surveillance and presents a strong possibility of future need for intervention. In recent decades, and largely because of successful efforts to replace the aortic root prophylactically, the lives of patients with Marfan syndrome have been prolonged such that issues beyond the root, such as concerns related to the peripheral arteries, have become more important. In particular, Schoenhoff and colleagues ${ }^{1}$ describe their experience regarding 48 patients with aortic dissection, 33 of whom had 66 related or

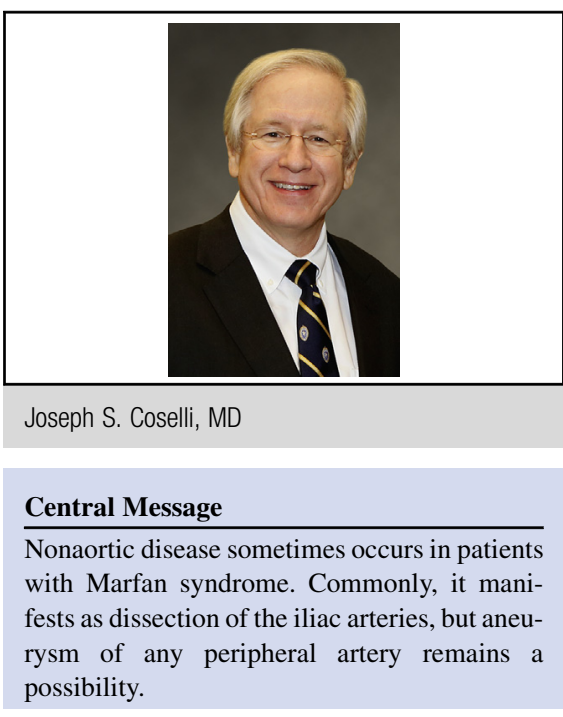

See Article page 2150.

unrelated dissections in nonaortic arterial segments. The majority of these dissections affected the iliac arteries $(40 / 66,61 \%)$. During the follow-up period, the authors carried out 34 interventions in these nonaortic arterial segments in 19 patients. The majority $(19 / 34 ; 56 \%)$ of these interventions were for the iliac arteries. Although the methods of intervention were not clearly specified, interventions were performed by open or endovascular approaches (only the use of coiling was clearly described). The authors importantly point out that in addition to there being little information on normal arterial dimensions, there is virtually no information on diameter-based thresholds for intervention. Notably, such thresholds should be set according to the cause, anatomic location, growth rate, and structure of the aneurysm, as well as other patient-specific factors. Despite the general lack of information, ultimately, the authors state that they operate on peripheral arterial aneurysms in patients with Marfan syndrome once the aneurysm has reached a diameter of 2.5 to $3 \mathrm{~cm}$, and largely regardless of its specific location.

Importantly, this article highlights the paucity of information on peripheral arterial aneurysms for virtually all forms of connective tissue disorder. Hopefully, it will stimulate further investigation into the size of normal peripheral arteries, as well as the natural history of peripheral aneurysm in patients with and without connective tissue disorders and those with and without dissection. Expert consensus documents generally contraindicate the use of endovascular 
aortic repair in patients with a connective tissue disorder. ${ }^{5,6}$ Much less is known about the endovascular treatment of peripheral arterial aneurysm in patients with Marfan syndrome, a technique that has proved valuable in treating atherosclerotic and other forms of peripheral aneurysm.

\section{References}

1. Schoenhoff FS, Yildiz M, Langhammer B, Jungi S, Wyss TR, Makaloski V, et al. The fate of nonaortic arterial segments in Marfan patients. J Thorac Cardiovasc Surg. 2019;157:2150-6.

2. Loeys BL, Dietz HC, Braverman AC, Callewaert BL, De Backer J, Devereux RB, et al. The revised Ghent nosology for the Marfan syndrome. J Med Genet. 2010; 47:476-85.

3. Johnston KW, Rutherford RB, Tilson MD, Shah DM, Hollier L, Stanley JC. Suggested standards for reporting on arterial aneurysms. Subcommittee on reporting standards for arterial aneurysms, ad hoc committee on reporting standards, Society for Vascular Surgery and North American chapter, International Society for Cardiovascular Surgery. J Vasc Surg. 1991;13:452-8.

4. Thrush A, Hartshorne T. Peripheral Vascular Ultrasound: How, Why, and When. 2nd ed. Edinburgh; New York: Churchill Livingstone; 2005.

5. Hiratzka LF, Bakris GL, Beckman JA, Bersin RM, Carr VF, Casey DE Jr, et al. $2010 \mathrm{ACCF} / \mathrm{AHA} / \mathrm{AATS} / \mathrm{ACR} / \mathrm{ASA} / \mathrm{SCA} / \mathrm{SCAI} / \mathrm{SIR} / \mathrm{STS} / \mathrm{SVM}$ guidelines for the diagnosis and management of patients with thoracic aortic disease: a report of the American College of Cardiology foundation/American Heart Association task force on practice guidelines, American Association for Thoracic Surgery, American College of Radiology, American Stroke Association, Society of Cardiovascular Anesthesiologists, Society for Cardiovascular Angiography and Interventions, Society of Interventional Radiology, Society of Thoracic Surgeons, and Society for Vascular Medicine. Circulation. 2010;121:e266-369.

6. Erbel R, Aboyans V, Boileau C, Bossone E, Bartolomeo RD, Eggebrecht H, et al. 2014 ESC guidelines on the diagnosis and treatment of aortic diseases: document covering acute and chronic aortic diseases of the thoracic and abdominal aorta of the adult. Eur Heart J. 2014;35:2873-926. 